\title{
RASGOS DE LA LITERATURA APOCALÍPTICA EN EL POEMA DE LA BESTIA Y EL ÁNGEL DE JOSÉ MARÍA PEMÁN
}

\author{
Katarzyna Madyjewska \\ kasiam@hotmail.com
}

\section{RESUMEN}

El artículo presenta el Poema de la Bestia y el Ángel, de José María Pemán, como una obra que integra la mayoría de los rasgos de la literatura apocalíptica: su estructura, planteamiento, contenido y procedimientos alegóricos. Este estilo literario no se ciñe sólo a la literatura espiritual, sino que también surge en tiempos de crisis políticas y sociales a lo largo de la historia. En el marco de las turbulentas sacudidas que afectaron a Europa en los primeros decenios del s. XX, el Poema se inscribe en una serie de obras, compuestas en circunstancias similares por varios autores y en distintos países, que utilizan los moldes apocalípticos, aunque en este caso se trate de un Apocalipsis popular.

Palabras Clave: Pemán; Literatura apocalíptica; Guerra Civil.

\section{ABSTRACT}

The article presents the Poem of the Beast and the Angel by José María Pemán as a work that integrates the majority of features of the apocalyptic literature: its structure, approach, contents and allegorical method. This kind of works is not limited only to a sacred canon but also appears in times of political and social crisis throughout the history. The Poem sets itself in the line of works composed in similar circumstances, that is during the turbulent events that affected Europe in the first decades of the age $\mathrm{Xx}$, by 
(1045). Son imágenes siniestras, pero las características más expresivas se reservan a la Bestia: «la Bestia inmunda de ojos sin luz y cola/ de dragón» (1002), monta un carro de la muerte en forma de un sapo «inmenso de hierro invulnerable» (1032). Se arrastra por el polvo, como la serpiente del paraíso:

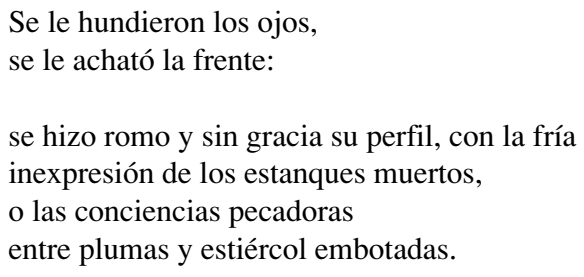

Se achicaron las patas y se agachó en el polvo, sin estatura, igual que los reptiles o el soplo bajo de la tarde que hace danzar las hojas. (1032-1033)

Las obras apocalípticas destacan por su lenguaje repetitivo y se construyen con categorías que estructuran el tiempo e introducen símbolos numéricos. Su repetición hace significativas las peripecias históricas y suscita emociones en los lectores, aunque no podemos esperar correspondencia exacta entre un número simbólico y la realidad. Su valor arbitrario consiste precisamente en recordar que reflejan las proporciones y analogías por encima de cualquier entendimiento o comparación ${ }^{62}$. Pemán reconoce sobre todo el valor del número tres: «número místico, redondo y perfecto. Número del tiempo - antes, ahora, después-; número de la generación — padre, madre, hijo—; número de la verdad humana —afirmación, negación, síntesis—... y sobre todo, número de Dios» (928). De hecho, el poeta empieza en nombre de la Trinidad, divide el poema en tres cantos, enumera tres iglesias: de la fe (San Pedro), del amor (San Juan) y de la esperanza (España de Santiago). Además prefiere cadenas triples de sustantivos o adjetivos. Las tres hadas traen tres dones «viejos, nobles e ilustres», conversan tres elementos: aire, viento y nube; habla de la Iglesia «de la Pasión, el Impetu, el Afán» (963), menciona «Cruz, trono, espada» (971), «la Muerte, la Pena, la Negrura» (1002), en el cuadro de El Greco ve «el Cristo, la Paloma y el Ángel», etc. Se fija en las tres virtudes «la Alegría, la Fe y el Amor» (1073), de las que la alegría corresponde en Pemán a la esperanza.

El número 7, símbolo de la perfección de la cuenta del tiempo, de los arcángeles y del lazo entre el cielo y la tierra, aparece con menos frecuencia: en los siete arcos iris (935), los siete sellos (936) y siete doncellas mitológicas (976). El número dos configura las maldiciones, las batallas con los judíos (por la Cruz y por el oro), la segunda túnica de Dios repartida, las águilas de Roma y Germania, los perros, y dos nombres de las islas (Baleares y Canarias). Entre otras claves de análisis se encuentras los 4 animales y los 4 jinetes que salen del abismo (940). Los 24 ancianos duplican el número tradicional de los 12 Apóstoles y patriarcas (935) y aparecen en el Apocalipsis $(19,4)$. El poeta se

${ }^{62}$ Cf. ibid., p. 55. Lozano Escribano, Jacinto y Anaya Acebes, Lucinio: op. cit., p. 60. Yarbro Collins, A.: op. cit., p. 14. 
permite variaciones libres en torno a los números tradicionales del apocalipsis, así que a los siete candelabros-iglesias añade el octavo-España, y el octavo ángel de España. A las siete cabezas y diez cuernos de la bestia (Ap 13,1), que el poeta explica como épocas de la persecución, añade la undécima corona destinada a perseguir España $(939,941)$.

En número mil normalmente se entiende como la vida eterna y el símbolo del reinado de Cristo, cuando la bestia está encadenada. Pemán con frecuencia amplifica pero en sentido negativo de la universalidad del mal: las mil chimeneas blancas del capitalismo (970), «Miles de hombres azules», «mil vientres hartos, las mil cadenas de oro» (970) «mil brazos de pulpo» (971), etc. El único caso positivo es en referencia a la tradición: «las piedras milenarias» (1063). Amplificaciones a escala menor se manifiestan en los cien ministros (970), cien manos al lado de la tumba de Calvo Sotelo (974), cien pupilas del Tajo (1014).

El Poema también ofrece un característico repertorio de diversas piedras preciosas: «trono de jaspe» (934), «ejes de diamante» (941), «arca de oro y de pedrería» (938), «campos de turquesa y zafir» (986). La hierba tiene el tono de esmeralda y en la España renovada: «Sus cimientos se han hecho con un oro divino» (1061).

El manejo de los colores remite a los usos tradicionales: la deslumbrante blancura del mundo divino, el rojo del fuego y de la sangre en la guerra y destrucción. El color azul funciona en dos niveles, que remiten tanto al cielo como al paraíso terrenal de un régimen político. Las connotaciones negativas se atribuyen al amarillo, el color de la traición, del oro y de la Bestia $(951,969,970)$.

A modo de resumen, podemos decir que el Poema hubiera ganado en calidad y expresividad de haber sido escrito después de la guerra, dado que lo que pretende hacer es un apocalipsis a escala nacional, y los requisitos de esta forma literaria suponen la distancia. Ella existiría si el poeta se hubiera dado más tiempo para elaborar sus impresiones y si de hecho no hubiera recorrido los frentes, lo cual incrementó el compromiso personal en su obra y disminuyó la distancia. De todas formas, es la única muestra tan extensa de un poema apocalíptico sensu stricto en el suelo español de principios del s. XX. El Poema es un ejemplo interesante de la incorporación del legado histórico y filosófico inmediato dentro de la tradición religiosa y literaria arraigada en los siglos de la cultura universal. 
various authors in various countries. It uses apocalyptic patterns although in this case it is a popular Apocalypse.

KeY wORDS: Pemán; Apocalyptic literature; Civil War.

Son numerosos los artículos y estudios dedicados a la literatura de la Guerra Civil española, sin embargo, en muchos casos, se interpreta su valor a partir de la complicidad de los autores con los enfrentados idearios político-sociales, así que el Poema de la Bestia y el Ángel (1938), de José María Pemán, suele enumerarse entre las obras representativas de una ideología. Este enfoque y las opiniones sobre su papel y calidad se encuentran en otros estudios ${ }^{1}$. En esta ocasión analizaremos el Poema como una obra que reúne numerosas características del género apocalíptico, aparte de que se escribió en las circunstancias casi «clásicas» de muchos de los apocalipsis y repite su estructura formal y de fondo: el imperio, el progreso y la catástrofe, la sucesión de desastres, la decadencia y renovación, el juicio ético de las naciones y de los individuos, consolidación de la doctrina, la misión de orientar la historia enfatizando valores determinados, etc ${ }^{2}$. Según las asociaciones tradicionales, una guerra revela dicotomía entre lo terrenal y celestial, mientras que en este caso se presenta como sintonía entre los dos planos. La Guerra Civil española es considerada por José M. Sánchez como «una de la grandes guerras míticas de nuestro tiempo», que en ambos lados se revistió de altos ideales y se mitologizó ${ }^{3}$. La vinculación de un acontecimiento a un mito consigue verlo desde una óptica nueva, «cuando se lo relaciona con algo ajeno al momento inmediato» ${ }^{4}$.

Debido a sus características y alcance, las guerras favorecen obras extensas, epopeyas incluidas. Siguiendo la intención del poeta, de escribir un poema épico, también hay que contar con la relación entre los poemas épicos y la alegoría, que es un recurso propio de este género. La literatura apocalíptica echa mano con frecuencia de la alegoría, a la que por antonomasia le son propias las polarizaciones y el poder persuasivo. Dice Angus

${ }^{1}$ Por ejemplo: Lechner, Jan (1968): El compromiso en la poesía española del s. XX. Vol. I, Leiden, Universitaire Pers, pp. 218-226; (1981) «Pemán: entre el ángel y la bestia», Quimera, n. ${ }^{\circ}$ 12, octubre, pp. 8-12. López Anglada, Luis (1965): Panorama poético español. (Historia y Antología 1939-1964), Madrid, Editora Nacional, pp. 31-32. MARTín, Eutimio (1979): «Pemán, poeta del nacional-catolicismo español», Cahiers d'Etudes Romanes, n. ${ }^{\circ}$ 5, pp. 117-138. Penalva, Joaquín Juan (2003): «Poema de la Bestia y el Ángel, de Pemán: configuración literaria de una estética de guerra», Hesperia. Anuario de Filología Hispánica, n. ${ }^{\circ}$ VI, pp. 175-191. Rodríguez Puértolas, Julio (1986-1987): Literatura fascista española. Vol. II, Madrid, Ed. Akal, pp. 201-209. URRUTIA, Jorge (1981): «La literatura andaluza desde las vanguardias», en Historia de Andalucía. Vol. VIII, Barcelona, Cupsa-Planeta, p. 427.

2 Díaz, José Alonso (1973): Literatura apocalíptica, Madrid, PPC Edicabi, p. 125. GIET, Stanislaw (1960): El Apocalipsis y la historia, Madrid, Taurus, p. 38. KeRmode, Frank (1967): The sense of an Ending, New York, Oxford University Press, p. 29. Para una reflexión actualizada de la apocalíptica en sus fuentes judías originales, véase, por ejemplo, Collins, John J. (1998): The Apocaliptic Imagination: An Introduction to the Jewish Matrix of Christianity, 2. ${ }^{\mathrm{a}}$ ed., Cambridge.

3 Cada bando creía representar los ideales puros enfrentados con el enemigo diametralmente opuesto. Sánchez, José M. (1987): The Spanish Civil War as a Religious Tragedy, Notre Dame, University of Notre Dame, p. 205.

${ }^{4}$ Es un procedimiento frecuente en la poesía griega clásica, la poesía china y también en la cristiana. BowRA, Cecil M. (1966): Poesía y política (1900-1960), Buenos Aires, Losada, p. 112. 
Fletcher que algunas alegorías cumplen «la función apocalíptica» cuando pretenden instaurar una «significación final», que se da, en palabras de Carlo Levi, cuando «el sentido del mundo se sitúa fuera del mundo» ${ }^{5}$. Un apocalipsis reacciona a una situación histórica pero «traspasa el horizonte histórico concreto, para adentrarse en una dimensión metahistórica. Será, por tanto, en el futuro, en la metahistoria, donde se consumarán los acontecimientos revelados» ${ }^{6}$.

El Poema ve el origen y el desenlace del conflicto bélico fuera de la realidad empírica. Cuenta con núcleos alegóricos típicos: el mensaje directo, el lenguaje esópico, la codificación simbólica accesible y sin admitir su ambigüedad, la confrontación de fuerzas opuestas en un juego batalla-progreso, el carácter fragmentario de los protagonistas, la actuación en el límite de lo humano y lo divino, imágenes micro y macrocósmicas, la magnitud del panorama, la intención de despertar el entusiasmo por los valores alegorizados, la simulada presencia del genio inspirador, la prevalencia del tema sobre la acción, la persecución de sentimientos sublimes, un mensaje inspirado por la divinidad, etc ${ }^{7}$. Estas características manifiestan que existe un género específico que encierra a la vez la alegoría y la apocalíptica.

Este género ofrece una interpretación que pocas dudas admite, por lo cual A. Fletcher habla de su crisis en la época moderna que duda de todo y, según N. Frye, recuerda lo antialegóricos que son nuestros tiempos ${ }^{8}$. Es también una época antiépica. De principios del s. XX suele destacarse El Virulo. Mocedades (1924), Virulo. Mediodía (1927) de Ramón de Basterra y el Poema de la Bestia y el Ángel de Pemán. Coinciden en las nostalgias imperiales, pero sólo el segundo añade la interpretación apocalíptica de la historia por la cercanía del conflicto bélico. La creación de esos dos autores contribuyó a la común opinión de que la épica y la alegoría se daban más a los autores «de derechas». Sin embargo, Anthony L. Geist realizó una comparación entre el Poema y Acero de Madrid (1938), una epopeya concebida por el poeta del bando republicano José Herrera Petere. Las razones ideológicas favorecieron el empleo de esta forma, pero sin que sea en exclusiva. A. Geist intenta criticar a Pemán, en lo que difiere de Acero, porque sólo la victoria le da sentido, «se expresa en términos abstractos y sólo rara vez da una sensación real o inmediata de batalla y muerte», «desmiente la cronología». El enfrentamiento entre la Bestia en un carro blindado y el Ángel no le convence porque en realidad los nacionalistas tenían más tanques. El mérito de Acero consiste en las escenas realistas, el detalle de la muerte, la minuciosa cronología, y la fidelidad exacta a los hechos, etc. ${ }^{9}$. Así

5 Fletcher, Angus (2002): Alegoría: teoría de un modo simbólico, Madrid, Akal, pp. 168, 342.

${ }^{6}$ Lozano Escribano, Jacinto y Anaya Acebes, Lucinio (2002): Literatura apocalíptica cristiana (Hasta el año 1000), Madrid, Polifemo, p. 26.

${ }^{7}$ Resulta útil la consulta de los libros de Cvitanovic, Dinko (1995): De Berceo a Borges. La alegoría en las letras Hispánicas, Buenos Aires, F. García Cambeiro. LEWIS, C. S. (1969): La alegoría del amor, Buenos Aires, Eudeba. Macqueen, John (1981): Allegory, London-New York, Methuen.

${ }^{8}$ Fletcher, A.: op. cit., p. 348.

9 Geist, Anthony L. (1990): «El ángel y la bestia: la poética de la batalla de Madrid durante la guerra civil», en Texto y sociedad. Problemas de Historia literaria, Ámsterdam, Rodopi, pp. 247-249, 250, 255.

En realidad, según las citas de A. L. Geist, ciertas nociones en las dos epopeyas son simplemente intercambiables. En Pemán es Dios quien inspira su poesía, mientras que en Herrera Petere encontramos: «La Política es la nube de fuego que guía la nueva Poesía», con claras alusiones al paso de los Israelitas por el desierto. El primero proclama unir la vida y la poesía (916-918), mientras que el segundo dice «el Pueblo y la 
que el crítico daría su visto bueno más bien a una epopeya que tenga características de una enciclopedia en versión poética.

A este respecto, nos parece esclarecedora la reflexión de C. S. Lewis, sobre que las alegorías y los poemas extensos son tan poco familiares al lector moderno, porque éste a menudo espera un mensaje transmitido en formas conocidas. Mientras que deberíamos preguntarnos primero, qué tipo de composición eligió el poeta, y recordar que cualquier elección supone renunciar a lo ajeno a ella y someterse a las leyes que ella impone. Al lado de lo que quiere decir el poema, vale la pena preguntarnos, qué es lo que el autor hace. Y resume Lewis: «Es como condenar una ópera o un oratorio porque los personajes cantan en vez de hablar» ${ }^{10}$. Pemán quiso hacer una epopeya y según Luis García Iglesias es discutible el resultado épico del Poema ${ }^{11}$. No obstante, el planteamiento y las sugestivas ilustraciones de Carlos Sáenz de Tejada, que acompañaron la primera edición de 1938, sugieren que otro propósito fue escribir un poema apocalíptico, y las pautas que sigue son precisamente las criticadas por A. L. Geist. Sin tenerlas, ya no sería apocalíptico. La poesía apocalíptica selecciona y condensa sus elementos y destaca por su enorme subjetivismo, pero al mismo tiempo se plantea un propósito alto de interpretar la historia. Los intervalos de destrucción y renovación se describen de paso. Destaca Cecil M. Bowra que un poeta vidente, a diferencia del poeta soldado, se veía impulsado a escoger entre un abundante material histórico obvio y centrarse en esos aspectos que, compaginados, puedan crear un impacto de una interpretación nueva. Pueden ser los eventos menores, sin resonancia significativa en las crónicas de la guerra ${ }^{12}$. Pemán emprendió un poema apocalíptico frente a la experiencia inmediata de la guerra que todavía transcurría ante sus ojos, lo escribió recorriendo en persona los frentes. De contar con una distancia temporal, un poema así sería fruto de la síntesis, de un conocimiento de oídas y del recuerdo romántico alejado ya en el tiempo ${ }^{13}$.

El apocalipsis significa en griego revelación y se propone desvelar el sentido de las violentas crisis en forma de visiones. Suele recordar el pasado del pueblo para fortalecer su idiosincracia. En el conflicto con otras naciones asegura la victoriosa acción divina en su favor y que las calamidades más incomprensibles no se escapan del control de la Providencia. Las injusticias se presentan como destellos de la contienda entre el bien y el mal, entre los que no hay ninguna posibilidad de compromiso ${ }^{14}$. En casi todos los pueblos

\footnotetext{
Poesía están más cerca que nunca». La guerra apocalíptica de Pemán no se aleja mucho del concepto de Acero, en que la política es «rico manantial de sangre que nos trae el pueblo» (pp. 248, 251). Queremos rectificar la hipótesis del crítico, para quien el ángel que cae en el nihilismo es una alusión a Sobre los ángeles de R. Alberti (p. 248). La raíz del planteamiento pemaniano de que la poesía sin el soporte del Ser como un ángel cae en el abismo, se encuentra en Fronteras de la poesía y otros ensayos de Jacques Maritain, de quien Pemán fue un asiduo lector ((1945): op. cit., Buenos Aires, La Espiga de Oro, pp. 16-18, 28).

${ }^{10} \mathrm{C}$. S. Lewis reconoce que él mismo a veces incurrió en el error de criticar el contenido de un poema, que en realidad fue el necesario para conseguir lo que el autor había pretendido. En (1963): A Preface to Paradise Lost, London, Oxford University Press, pp. 1-3, 40.

${ }^{11}$ García Iglesias, Luis (1997): 'Poema de la Bestia y el Ángel' de José María Pemán: verso y composición métrica, Madrid, Artes Gráficas/ Tajo Guadiana, p. 12.

12 Bowra, C. M.: op. cit., p. 39.

13 Ibid., pp. 12, 25, 102.

${ }^{14}$ Cf. Díaz, J. A.: op. cit., p. 22. Fatás, Guillermo (2001): El fin del mundo. Apocalipsis y milenio, Madrid,
} Marcial Pons, p. 83. GIET, S.: op. cit., p. 310. 
y culturas solía resurgir la apocalíptica en los momentos de grandes perturbaciones sociales, religiosas o económicas. Raras veces aparecía en el tiempo de paz, que propiciaba más bien la literatura sapiencial. Las más conocidas son las profecías apocalípticas de la Biblia: de una parte de Isaías, Daniel, Ageo, Zacarías, y por supuesto el Apocalipsis de San Juan, que determinó las pautas de muchos apocalipsis posteriores. El género alcanzó su auge entre 250 a. C. y 150 d. C., entre los judíos y los primeros cristianos, pero seguía apareciendo a lo largo de toda la Edad Media, también en España ${ }^{15}$. La literatura apocalíptica floreció lógicamente alrededor del año 1000 por las expectativas de la segunda venida y el reino milenario de Cristo, anunciado en el Apocalipsis. Sin embargo, los autores a menudo hacían sus propios cálculos para indicar el fin del tiempo, así que para algunos iba a ser decisivo el año 800, el 1640, o 1927 para Yeats. Pemán no hace cálculos sofisticados, pero remite a este esquema: «Y este que nace es año milenario de espantoso terror» $(930)^{16}$. La fecha así entendida suponía un cumplimiento de algún ciclo histórico importante y una transición crucial. En fin, menciona que los siete sellos ya están quitados (936). Además, es curioso observar que las fechas milenarias coincidían con el despertar de las mitologías imperiales, que el caso del Poema confirma $^{17}$.

Las características de los apocalipsis se encuentran en las famosas obras de Legenda Maior de San Buenaventura, Roman de la Rose de Jean de Meun, o en la peregrinación de Dante a través del infierno. Más adelante el peso de su contenido se desplazó hacia la interpretación de la historia contemporánea de sus autores. Encontró un suelo fértil en toda la Europa del s. XVII y XVIII. El desarrollo de las ciencias no quitó el misterio a esas profecías que reaparecieron incluso en ausencia de persecuciones, con motivo de alguna conjunción de astros u otros eventos naturales a gran escala, como en el caso del físico Newton (s. XVII/ $\mathrm{XVIII}^{18}$. Recuerda Elinor Shaffer que los poetas que reclamaron funciones proféticas en el romanticismo (Coleridge, Wordsworth, Blake) no usurparon abiertamente el papel de un autor judeo-cristiano del pasado inspirado por el Espíritu Santo, sino que se conformaron con un «presentimiento» y disfrutaron de la imaginería apocalíptica con fines seculares: los sueños sobre el futuro, matrimonios místicos, viajes al infierno, etc. Cuando se redefinían las políticas de las naciones de las primeras décadas del s. XIX, la posibilidad proporcionada por el enfoque apocalíptico, de intervenir también en el pasado, sin duda atrajo a los poetas $^{19}$. Éste es uno de los rasgos principales del que se beneficia el Poema de Pemán, que recorre la historia nacional y todos sus participantes aparecen como si se tratara de la última escena de una obra teatral en la que salen todos los actores.

${ }^{15}$ En los textos apocalípticos la dimensión mística y la socio-política a menudo se compenetraban y condicionaban. Díaz, J. A.: op. cit., p. 226. Lozano Escribano, Jacinto y Anaya Acebes, Lucinio: op. cit., pp. 216 y ss. FATÁS, G.: op. cit., p. 108. Yarbro Collins, Adela (1996): Cosmology \& Eschatology in Jewish \& Christian Apocalypticism, Leiden, E. J. Brill, p. 2.

${ }^{16}$ Los números de las páginas del Poema se citarán en adelante directamente en el texto, según la edición en Pemán, José María (1947): Obras completas. Vol. 1. Poesías de Madrid, Escelicer.

17 Kermode, Frank (1966): «The New Apocalyptists», Partisan Review, vol. XXIII, n 3, Summer, p. 341.

18 Emmerson, Richard K. y Herzmann, Ronald B. (1992): The Apocalyptic Imagination in Medieval Literature, Philadelphia, University of Pennsylvania Press. (2001) Millenarianism and Messianism in Early Modern European Culture. Vol. III, (eds. James E. Force, Richard H. Popkin), Dordrecht, Kluwer Academic Publishers. GIET, S.: op. cit., p. 293.

19 Shaffer, Elinor (1998): «El Apocalipsis secular: profetas y apocalipsistas a finales del siglo XVIII», en $L a$ teoría del apocalipsis y los fines del mundo, (ed. Malcolm Bull), México, Fondo de Cultura Económica, p. 179. 
La tragedia de la I Guerra Mundial contribuyó al resurgimiento de las imágenes apocalípticas. Robert Detweiler habla incluso de la «apocalíptica mentalidad moderna» que inevitablemente se refleja en la literatura ${ }^{20}$. Cecil M. Bowra describe la «aparición súbita» y «oleada común» de la nueva poesía profética a principios del s. XX en Europa ${ }^{21}$. Las imágenes apocalípticas se encuentran en The Waste Land (1922) de T. S. Eliot, en las obras de D. H. Lawrence, «One-Way Song» (1933) de Wyndham Lewis en Inglaterra, en The Vision (1927) del irlandés W. B. Yeats, en Georg Heym de Alemania, Georg Trakl en Austria, Constantine Cavafy en Grecia, Victor Khlebnikov en Rusia ${ }^{22}$. En España pertenece a esa corriente la novela de Vicente Blasco Ibáñez Los cuatro jinetes del Apocalipsis (1916). Juventino Caminero destaca una veta apocalíptica en Poeta en Nueva York (1929-1930) de F. García Lorca. Aunque en este caso el poeta actúa a la inversa: renuncia a la apocalíptica Jerusalén en favor del paraíso terrenal y revierte muchas nociones ${ }^{23}$. Con más subjetivismo, sin pretensiones escatológicas ni esperanza de la intervención divina, se puede mencionar en este contexto «Sobre los Ángeles» (1929) de R. Alberti, que amplió la perspectiva en «El poeta en la calle» (escrito en 1931-1935) ${ }^{24}$. En este punto, Jacinto Lozano Escribano y Lucinio Anaya Acebes plantean el problema importante de la interacción entre apocalipsis y literatura. Las obras literarias aprovechan el uso de símbolos apocalípticos sin pertenecer formalmente a su género y al revés, algunos escritos que le pertenecen pueden hacer caso omiso de sus características más relevantes. Los críticos aluden al debate de si se trata de un fenómeno divulgador de un tipo de pensamiento que excede el género literario porque es propio también de las culturas no cristianas ${ }^{25}$. La representación de la decadencia en términos apocalípticos se ha vuelto inherente al lenguaje de la cultura ${ }^{26}$.

Sin duda se trata de un modelo de gran potencialidad para la literatura. Los apocalipsis se escribían para un gran público y correspondían a una especie de literatura «popular» ${ }^{27}$. De ahí que Pemán aprovechó el modelo que rendía como medio de propaganda masiva en la Guerra Civil. Frank Kermode recuerda que en el mismo período también «Guernica», el cuadro de P. Picasso, refleja la imaginería medieval apocalíptica ${ }^{28}$. La alusión a la herencia cultural comúnmente conocida facilitó la comunicación. En la época de la rehumanización de la poesía en España, la creación comprometida de derechas se refería abundantemente a las nostalgias imperiales y la añoranza del Siglo de Oro, cuya configuración socio-cultural se convertía en el ideal ${ }^{29}$. El nacionalismo en este caso

${ }^{20}$ Detweiler, Robert (1990): «Apocaliptic Fiction and the End(s) of Realism», en European Literature and Theology in the Twentieth Century, (ed. David Jasper and Colin Crowder), London, Macmillan Press, p.153.

${ }^{21}$ Bowra, C. M.: op. cit., p. 95.

${ }^{22}$ Ibid., p. 56. Kermode, F.: «The New Apocalyptists», pp. 339-361. Mackenzie, Donald (1990): «After Apocalypse: Some Elements in Late Lawrence», en European Literature and Theology in the Twentieth Century, (ed. David Jasper and Colin Crowder), London, Macmillan Press, p. 36.

${ }^{23}$ Cf. (1998) Poesía española del siglo XX, Kessel, Edition Reichenberger, p. 223.

${ }^{24}$ Desde otro lado ideológico opta por el paraíso material de la Utopía del socialismo y también ahonda en el pasado en el recuerdo de la unidad del pueblo en Fuenteovejuna deseando que se repita en España. Cf. DALE MAY, Barbara (1978): El dilema de la nostalgia en la poesía de Alberti, Bern, Peter Lang, pp. 35, 55.

${ }^{25}$ Lozano Escribano, J. y Anaya Acebes, L.: op. cit., p. 26.

${ }^{26}$ MACKenZIE, D.: op. cit., p. 35. Cf. Kermode, F.: «The New Apocalyptists», p. 361.

27 Díaz, J. A.: op. cit., p. 221.

${ }^{28}$ Kermode, F.: The sense of an Ending, p. 95.

29 Sobre el motivo de la rehumanización de la poesía dice J. Juan Penalva: «Pemán se refiere a este proceso, lo que ocurre es que lo está descontextualizando y llevándolo a su propio terreno». Op. cit., p. 183. 
propicia una obra de características apocalípticas. Subraya José Alonso Díaz que cuanto más nacionalista era el pueblo, con más sensibilidad se dolía por su eclipse y era más propenso a buscar consuelo en la visión del futuro glorioso trazado en los apocalipsis ${ }^{30}$. El florecimiento del género apocalíptico solía coincidir con las tendencias nacionalistas también en el siglo XIX y XX. Los poetas que aprovechaban los motivos apocalípticos solían reclutarse de entre los partidarios de movimientos nacionalistas ${ }^{31}$.

En el Poema lo que entra en juego, al lado de la fidelidad o infidelidad a Dios, es sobre todo el concepto de fieles e infieles a la tradición y a la idea del imperio. España a veces sustituye el nombre divino y es un centro religioso del mundo. El soldado-ángel lucha contra la Bestia con el nombre del país como lema (1039), el embajador italiano dice: «creo en España» (1048). España copia la actitud de la Virgen: «Soy la esclava del Señor» (1064). La maldición contra Lenin se lanza en nombre de España (1066). Los nardos españoles crecen en la tierra «en la Anunciación» (1069). Aprovechando el motivo de los dos caminos, el poeta profetiza el futuro en detrimento de Francia, castigada por la elección de una senda inoportuna (1065). La reina Isabel es semi celestial (1057). España sustituye a la nueva Jerusalén (1055), se asienta en los cimientos de oro, vive una nueva alborada y el orden divino (1067). A ella afluyen las demás naciones y ella representa a todo Occidente.

En su afán de idealizar, el poeta presenta al Ángel aragonés rubio, y en la quintaesencia de la reina castellana subraya su rubia melena y ojos azules. Curiosamente él ve a los españoles así, aunque en otro sitio, los pueblos rubios del este encarnan el mal $(1009,1062)$. Probablemente este ideal le pareció adecuado en contraste con los árabes y los africanos. El Poema ensalza el pasado del país, introduciendo a los personajes literarios e históricos: Lazarillo, Don Quijote, los santos Teresa e Ignacio, los reyes, los conquistadores, y otros. Prácticamente yuxtapone el imperio y Dios (1067). Los elegidos reciben una misión especial de guiar a los demás (1052). El sueño del mundo venidero se cumple en la restauración de la monarquía, en vez del reino mesiánico. El cordero se casa no con la Iglesia universal sino con España en particular. La instauración del reino de la «España Azul» sugiere la dimensión celestial, pero en esta ocasión se trata del régimen político (1051). Los autores apocalípticos suelen recibir resignados, como designio divino, las desgracias ya acaecidas, mientras que el Poema incita a la cruzada (1056) y posteriormente busca excusas y apoyo sobrenatural. Los apocalipsis permiten la reinterpretación del pasado y revisión de las interpretaciones anteriores. En consecuencia, en el Poema la historia ha preparado el desenlace feliz de la guerra. Podemos decir que Pemán consigue un apocalipsis terrenal porque la Alegría profetiza la instauración del imperio en la tierra y no pretende trasladarlo más lejos.

Las referencias históricas reales se alternan en proporción igual con las mitológicas, que desrealizan los acontecimientos. Pero por otro lado, la mitología es inherente a casi todos los apocalipsis, de un modo más o menos disimulado. La mezcla de diversas tradiciones culturales impide que sean obras unitarias ${ }^{32}$. No es unitario el Apocalipsis de

${ }^{30}$ Díaz, J. A.: op. cit., pp. 38, 223-224, 226.

${ }^{31}$ Fuera de España se considera como un caso representativo de ese fenómeno a Yeats, Wyndham Lewis, Ezra Pound, etc. Cf. Kermode, F.: «The New Apocalyptists», pp. 349, 351.

${ }^{32}$ Delcor, Mathias (1977): Mito y tradición en la literatura apocalíptica, Madrid, Cristiandad, pp. 111, 140. Fatás, G.: op. cit., p. 90. Yarbro Collins, A.: op. cit., p. 6. 
Juan, ni lo es el Poema. Pemán en el prólogo añade un enfoque literario: el pretendido fragmentarismo hace converger las diversas imágenes en el «prospecto». Por esta vía, el poeta señala que no se trata de un apocalipsis en sentido literal sino una creación poética. No pretende convencer de la veracidad de su visión, sino que la plantea como un juego intertextual. Involucra a las tierras y a los seres mitológicos: Atlántida, las Islas Afortunadas, las Hespérides, Afrodita, Prometeo, las ninfas, la Fortuna, y otros. La mitología le da la oportunidad de ampliar el universalismo cultural entre la antigüedad y la modernidad. Además el poeta dice que el pasado y el futuro son inseparables (1015) y que, entre el alfa y el omega de la historia, el pasado se manifiesta en el presente:

Entre el Infierno y Dios, entre el principio

$\mathrm{y}$ el fin de las edades, vuelve a ser Edad Media el siglo veinte. (1016).

Los autores apocalípticos proporcionan consuelo al asegurar que los eventos aparentemente inconexos hallan su sentido en el coherente plan divino. Así, en el Poema vemos la alegoría del destino que atraviesa la senda de la historia (1015) y se justifican las desgracias por la intervención divina (1013). El Poema pretende dar una explicación sobrenatural a la historia que de por sí sería enormemente complicada y difícil de abordar. Sitúa la guerra española en el centro de los grandes movimientos políticos y convierte a los españoles en un pueblo elegido, en el que se concentran todas las vicisitudes de las que hablan los apocalipsis, por la lucha de los poderes universales (cf. 990-991, 1063). El poeta mezcla su destino personal con el más universal de la humanidad. Junto a los datos geográficos y topográficos concretos entran en escena otros pueblos y continentes, al lado del mundo de los poderes cósmicos. La introducción sintetiza en una imagen sobrenatural lo que luego se desarrolla con imágenes también naturales. En el prólogo el poeta define su deseo de abarcar un cuadro total y de múltiples niveles:

En mi Poema (...) yo he querido ver la Guerra, no en su «aspecto» sino en su «prospecto», o sea en el bloque total de su contenido; en la compendiosa y simultánea revelación de todas sus capas superpuestas de hechos externos, contenido espiritual y significados futuros... $\mathrm{He}$ querido ver la Guerra (...) fundiendo en una sola imagen, la pluralidad temporal de sus gestos y momentos, y la pluralidad espacial de sus vestidos, su esqueleto y su musculatura (927).

Según el enfoque suprahistórico e inequívoco: «todo su profundo significado apocalíptico de revelación de la eterna pelea de la Bestia y el Ángel» (928). Este conflicto se presenta entre España y el Oriente rojo, del brazo con judíos y masones. Estos bien definidos binomios en el cosmos afectan otros conceptos polarizados: la guerra y la paz, la luz y la oscuridad, lo exacto y lo torcido, la verdad y la falsedad, la belleza y la fealdad, etc. La devastación contrasta con imágenes idílicas.

El poema apocalíptico, dirigido a las masas y centrado en los grandes problemas del universo, necesariamente describe las emociones primarias del amor, odio, alegría, triste$\mathrm{za}$, sin un tratamiento individual de los personajes que menciona. Se mueve entre las simplificaciones de situaciones y tipos humanos. Del mismo modo, el vocabulario realza las realidades limítrofes, como la sangre, el hierro, pero también la rosa, la dulzura, etc. Las experiencias humanas se entienden como la bendición o el castigo, la obediencia o de- 
sobediencia ${ }^{33}$. El contraste se da entre el despliegue de los cuadros universales de la historia, las perturbaciones cósmicas y la desproporcionada intensidad del tiempo corto de la guerra.

El Poema oscila entre contrastes, según los requisitos del dramatismo apocalíptico. Las imágenes morbosas y consoladoras se alternan simétricamente. La escena del Alcázar hace eco de los claroscuros del cuadro de El Greco El entierro del conde de Orgaz, pero al lado de la oscuridad de las ruinas la luz tiene una procedencia más bien sobrenatural. Contrasta «la guerra/ de la luz y la noche» (1001), «la oscuridad de su inocencia», «indecisa luz ensangrentada» (1004). En otro sitio la sugestiva descripción de la walkiria irrumpe al lado de otra más pacífica. Podemos comparar:

Y aquella tarde, contra

las luces del crepúsculo sangriento,

una walkiria rubia, desmelenada al viento,

Y las uñas ensangrentadas de sus manos

repintadas, profanan la serena

tarde y la dulce Sagra de abejas de oro llena. (1009)

Sobre el aire novicio

la gracia de Dios brilla.

Las ninfas que escucharon los versos de Salicio

sentadas en la arena dorada de la orilla

del Tajo, oyen un trueno

(1010)

Incluye las imágenes lúgubres de la destrucción: «Desgarrados,/ como blancos lechales, tiernos niños/ festonan la ciudad» (997), o sugestivas como ésta:

Por la ciudad desierta va aullando un perro fiel

entre un espanto negro de piedras calcinadas:

y con locas miradas

va un niño en la tristeza de la mañana fría (...). (988).

Pero luego polariza las emociones hacia algún cuadro pacífico:

El aire se vestía

de nuevas transparencias, y la espuma

se rompía en encajes de mantillas (...). (1031).

Es de hecho muy apocalíptica la grandiosidad de las hipérboles que tienden a impresionar al receptor: «grande voz como trompeta», «ángeles del abismo» (940), «aliento de fuego, humo, azufre», «inmenso espejo azul del mar sin límites» (941), «y será (...) ojos de espanto/ la soledad desnuda de las eras» (951), «desde el más negro del abismo hasta el más alto azul», etc.

${ }^{33}$ Bultmann, Rudolf (1957): History and Eschatology, Edinburgh, The University Press, p. 18. 
El poeta desde el principio desrealiza la guerra y describe lo que pasa en el cielo en imágenes sublimes y extensas. Introduce los ángeles como unos seres intermedios. Según los moldes apocalípticos, Dios en el principio avisa de las calamidades. Enlaza toda la historia concreta con la dimensión cósmica de la gran batalla entre la Nada y el Ser, entre el diablo y Jesucristo. Desde el principio evoca el Paraíso y recorre las escenas evangélicas de modo que el Poema se convierte en una prolongación del cumplimiento de los tiempos (958 y ss.). La solemnidad del planteamiento se confirma en el anuncio de Séneca sobre los movimientos de las fronteras de los mares que cambiarán la faz del mundo (1068). O en la aparición de San Diego en un carro de fuego, a modo de los profetas bíblicos: «Venía vestido de rayos de tormenta:/ era como un inmenso vendaval bramador»; y que anuncia las desgracias (979).

Malcolm Bull menciona que lo apocalíptico religioso tiende a conmocionar y transformar a los receptores, pero mezclado con lo apocalíptico popular puede explotarse con fines políticos o sociales, de lo que el Poema sería un ejemplo ${ }^{34}$. Los autores apocalípticos no tenían reparo en copiarse uno a otro en cuanto a las fórmulas y los motivos, ni en referirse a sus antecedentes. Sus circunstancias socio-políticas les hacían transformar el presupuesto existente en función de las nuevas necesidades históricas y del futuro que querían moldear para su propia época ${ }^{35}$. También Pemán se ampara bajo la autoridad del apóstol Juan e incluye los conocimientos y corrientes ideológicas propias de su tiempo.

Los autores de los apocalipsis desplegaban cuadros inverosímiles ante los lectores, por lo que necesitaban de fundamento para sus palabras y recurrían a la pseudonimia. Fue un procedimiento muy divulgado en este género y consistía en elegir a algún personaje de prestigio del pasado para convertirle en el transmisor del mensaje o por lo menos contar con su presencia en el texto para subrayar su relevancia. Pemán elige a Homero como guía para dar más crédito a su visión, aunque guarda su propia identidad (931). Se apoya en la autoridad de este vate reconocido por su patrocinio sobre la épica y por haber vinculado la guerra con los poderes cósmicos.

Éste detalle, y el hecho de centrarse más en el presente que en el futuro, lo distingue de la literatura puramente profética, aunque contenga algunos elementos suyos ${ }^{36}$. Lo apocalíptico puede ser paralelo a lo profético, aunque suele ser más esperanzador, mientras que lo profético no necesariamente se muestra $\operatorname{tal}^{37}$. La forma de narrar muestra semejanzas y discrepancias con el Apocalipsis de Juan. El apóstol habla del futuro, pero relatando la visión que para él ya se ha concluido. Mientras que el autor del Poema al principio habla en el presente y, a pesar de emplear a continuación las formas del pasado, su visión se produce ante nuestros ojos. Evidentemente, el proyecto de volver a la épica cede sitio a la apocalíptica, ya que los poemas épicos solían escribirse sobre los acontecimientos del pasado. Por otro lado, los apocalipsis bíblicos hacen pensar en el futuro, mientras que Pemán relata algunos hechos a posteriori y otros que se desarrollan inme-

${ }^{34}$ Cf. Bull, Malcolm (1998): «Introducción: para que los extremos se toquen», en La teoría del apocalipsis y los fines del mundo, (ed. Malcolm Bull), México, Fondo de Cultura Económica, p. 15.

35 Giet, S.: op. cit., p. 262.

36 Cf. Shaffer, E.: op. cit., p. 168.

${ }^{37}$ Cf. Rowland, Christopher (1998): «Los que hemos llegado a los fines de los tiempos: lo apocalíptico y la interpretación del Nuevo Testamento», en La teoría del apocalipsis y los fines del mundo, (ed. Malcolm Bull), México, Fondo de Cultura Económica, p. 59. 
diatamente ante sus ojos. En este caso, es esclarecedora la nota de M. Bull: «En contraste con las escatologías religiosas elevadas, a menudo preocupadas por el pasado o por el futuro distante o indefinido, la escatología popular enfoca los hechos que ocurren en el presente y en el futuro inmediato ${ }^{38}$. Por ejemplo, el libro de Daniel presentaba como visión lo que ya era historia ${ }^{39}$. Pemán simplemente repite este procedimiento. Sin embargo, el contenido de la profecía a menudo ya pertenece al pasado, aunque el poeta finja otra cosa. Las dos maldiciones judías son en el texto profecías con un contenido que se cumple, aunque sean interpretaciones poéticas de los antecedentes. Es el modelo apocalíptico lo que permite un tono grandilocuente e impone distancia ante los hechos, incluso poco remotos.

De todas formas, el hablante desempeña aquí el papel del profeta apocalíptico que «intenta desligarse del presente para trasladarse a edades futuras, al fin del mundo, sin conseguirlo plenamente, creando por ello un cierto nivel de artificiosidad». En esto se diferencia del poeta vidente: «enraizado en su tiempo, que habla a su pueblo con el lenguaje calcado de la realidad misma ${ }^{40}$. Suponemos que el poeta vidente correspondería por ejemplo a la expresión del yo lírico en Poeta en Nueva York de F. García Lorca. Pemán más bien presenta una escena teatral, en la que participan los humanos y la creación, coordinada por las fuerzas invisibles ${ }^{41}$. En «Coloquio de los elementos» vemos cómo conversan los elementos celestes naturales y sobrenaturales: el aire, el viento, las nubes, las águilas y los ángeles, sobre el destino de la batalla que ha de librarse. El cielo contempla lo que sucede en la tierra. De ahí que el autor no apuesta por la exactitud enciclopédica de los hechos, ni por su cronología, sino más bien por su teología y escribe con una intención doctrinal. Faltan contornos agudos entre lo que es la historia y lo que es la visión poética. Obviamente, al representar la guerra no parte de la posición del poeta soldado, porque en el pensamiento apocalíptico el problema se soluciona Deus ex machina, sin la participación activa del transmisor ${ }^{42}$. No presta importancia a la veracidad de las visiones porque lo que cuenta en la apocalíptica es el receptor a quien quiere proclamar el mensaje sin aspirar a la historicidad en la exposición de los planes divinos ${ }^{43}$.

El poeta juega con el presupuesto de la tradición y de la Biblia. Homero fue ciego, mientras que aquí es nombrado «lazarillo» del autor. De esta manera se subraya la diferencia entre la ceguera física y la capacidad de ver en dimensiones invisibles. Al mismo tiempo, el poeta se declara «sin voz» (934). Más adelante oye un mandato: «Afila tus ojos, como espadas, si quieres ver (...) la pelea» (940). En la Biblia la espada corresponde a la agudeza de la palabra, y en el Apocalipsis sale de la boca del Hijo del hombre. Aquí el poeta está más interesado en ver con agudeza. Asume el papel del transmisor del mensaje y no su emisor, aunque en cierto momento interviene más activamente y lanza maldiciones por su propia iniciativa (995-996). También cuenta: «Y como yo pidiera al Señor un más claro entendimiento de su palabra, el Señor me pasó la mano por los ojos»

\footnotetext{
38 Bull, M.: op. cit., p 15.

${ }^{39}$ Cf. Díaz, J. A.: op. cit., p. 110.

${ }^{40}$ Lozano Escribano, J. y Anaya ACebes, L.: op. cit., p. 60.

${ }^{41}$ Id.

${ }^{42}$ Díaz, J. A.: op. cit., p. 62.

43 Shaffer, E.: op. cit., p. 184.
} 
(940). Justifica su arrebato por haber recurrido al poder divino. Otra vez compila las alusiones a la voz y a la vista, dado que fue a Isaías a quien un serafín le pasó las brasas por la boca para que pueda hablar (Is 6, 6-7). El poeta insiste en la precisión de la vista en el plano sobrenatural, a semejanza de Homero y a modo divino.

Los profetas apocalípticos a menudo se ven llevados a los cielos donde Dios les revela varios misterios y permite volver a la tierra para transmitirlos ${ }^{44}$. En el Poema el vidente describe las circunstancias de la misión encargada directamente por el poder superior. Gradúa la revelación de su procedencia, ya que empieza por la invocación a Homero; luego, a modo de poetas de antigüedad, a España y por fin a Dios, a quien pide que autorice su mensaje y le confiera la capacidad de contar la visión. Apoya su autoridad en lo que ve delante del trono divino. En la parte II es Dios mismo quien le manifiesta las visiones. A lo largo del Poema vuelve a asegurar que todo le ha sido revelado (934-936) y no lo inventa hablando, con lo cual ya se desprende del aval de Homero. De esta manera no toma parte en la batalla sino que la observa desde arriba y conoce de antemano los secretos de la Bestia. En adelante reitera la alusión a que la visión se transmite desde el punto de vista sobrenatural. En «Coloquio» sube a lo alto para oír mejor la conversación de los tres elementos y es narrativo como el apóstol Juan: «Y he aquí las altas voces que he escuchado en la cima» (978). Confirma su posición del que sabe más: «Mira desde mi altura» (980). En algún momento vacila si ése es el sueño o la realidad (999), pero finalmente enlaza con el principio reafirmando su autoridad: «esto que digo no es vana palabra/ (...)/ Mi palabra es de Dios» (1068).

Sugiere que la batalla de su tiempo pertenece a la gran tradición apocalíptica y muestra cierto parentesco con ella. Se propone hacer una especie de suplemento, cuando añade por su cuenta el octavo candelabro (934). A semejanza de San Juan, que primero declara el origen del mensaje y luego nombra a sus destinatarios, el poeta se dirige a España, la Iglesia del octavo candelabro, y anima a los oyentes aludiendo a las palabras de Jesucristo: «Que escuchen los que tengan oídos» (941). No pierde el contacto con ellos y de vez en cuando lanza avisos que recuerdan los poemas épicos de la antigüedad: «Levantad conmigo al paso/ (...)/ un pico del velo de la Historia» (965), «Os contaré la gran fábula prometeica...» (967). Los resúmenes anticipativos de las secciones captan la atención de los oyentes. La estructura de los apocalipsis se refleja en la distribución del contenido, que se desprende de la realidad visible y traza el despliegue grande de la acción, extendida al cosmos y al cielo. Empieza con la intención preliminar de impresionar con la gloria divina, tal como lo hace el apóstol Juan. Las imágenes iniciales de la majestad arrolladora de Dios, llenas de luz y blancura, remiten al Apocalipsis y su finalidad es convencer al receptor para que no dude del poder divino.

El poeta sabe más que otros y anuncia los desastres que aún desconocen, como en el fragmento «La niña de Talavera». Está por encima del tiempo y del espacio, y cuenta el pasado como si fuera el presente. Asume el papel de bisagra entre dos mundos y une los tiempos, como en «Los dones de las tres hadas», en la batalla del golfo de Lepanto: «yo vi flotar...» (1064), en el pasado cercano en Navarra: «Yo los vi en la noche...» (1024), o en el Alcázar de Toledo: «Mis ojos de poeta (...) vieron» (1003). En el Apocalipsis o el li-

${ }^{44}$ Cf. Díaz, J. A.: op. cit., p. 91. Giet, S.: op. cit., p. 41. 
bro de Daniel a veces es un ángel quien anuncia las calamidades o explica su significado al vidente. En este caso el poeta introduce la figura de San Diego, como una forma de pseudonimia, y otra se halla en los vaticinios puestos en boca de un ángel, del viento, de la sirena, de Séneca, o la Alegría personificada. Al dotarla de la cualidad «celeste», de nuevo enlaza con el poder sobrenatural. Además, si recordamos que en el poema equivale a la esperanza, podemos hablar del procedimiento típicamente alegórico de las virtudes personificadas, las teológicas en este caso. La Alegría-Iglesia española de la esperanza se enfrenta con el mal en una reminiscencia de psicomachia, la alegórica «lucha entre dos ejércitos de gérmenes morales enfrentados ${ }^{45}$.

Los apocalipsis destacan por la presencia de fragmentos que iluminan el sentido de la obra y proporcionan explicaciones morales ${ }^{46}$. El Poema repite este procedimiento, por otro lado muy común a toda la creación poética de Pemán. Inserta moralejas generales: «Una sola naranja basta para pudrir el cesto» (945), «La vida verdadera se vive en lo interior» (987), etc. Los apocalipsis propician los discursos inflamados y el afán didáctico. Proponen un programa de vida, de cómo vivir el tiempo y cómo transcenderlo ${ }^{47}$. También Pemán reflexiona que la guerra enfrenta al ser humano con el precio de la vida (1044).

Los apocalipsis vinculan estrechamente el sentido del comienzo, del medio y del final. Estructuran el tiempo en épocas definidas según el plan divino. Pemán divide el tiempo del Poema entre «Desde el principio de los tiempos», «En el centro de la historia» $\mathrm{y}$ «Hacia los tiempos nuevos». Y también divide el tiempo de la historia de España. Vemos que la presencia de las figuras históricas insertadas en medio de la batalla presente subraya la idea de la unidad de la historia. El recuerdo de la gloria pasada en los apocalipsis sirve de consuelo y autoafirmación. Con esta finalidad el Alcázar personificado suspira por el bienestar de la época de Recaredo y Carlos V (1003). Se sobreponen los planos temporal y eterno. El recuerdo del pasado lo hace paralelo al futuro y enlaza el origen con el fin de los tiempos ${ }^{48}$. Las tres principales partes del Poema ordenan la cronología e introducen separación entre el antes y después del tiempo. El planteamiento apocalíptico es socorrido por la idea de los «eones» de Eugenio D’Ors, con quien Pemán parecía sintonizar en este aspecto. También las lecturas del pensador ruso N. Alexandrovich Bardiaev propiciaron esta división de los tiempos que se alternan continuamente $^{49}$.

Dentro de la unidad del pasado, presente y futuro, asume la existencia de los kairoi, tiempos designados por Dios como puntos de intervención especial en la historia, que cambian su transcurso y deciden su sentido. La conciencia de los kairoi se refleja en numerosas alusiones. Dice la bestia: «Ésta es la hora» (941), más adelante encontramos: «Ha llegado la hora» (976), «Llegan horas malditas» (979), «Es la hora de las Masas» (980), el viento «sopla en las horas de la mala ocasión» (981). Otro fragmento anuncia:

${ }^{45}$ Fletcher, A.: op. cit., p. 195.

${ }^{46}$ Cf. Emmerson, R. K. y Herzmann, R. B.: op. cit., p. 100.

47 Yarbro Collins, A.: op. cit., p. 8.

${ }^{48}$ Cf. Giet, S.: op. cit., pp. 182, 235, 305.

${ }^{49}$ Cf. Álvarez Chillida, Gonzalo (1996): José María Pemán. Pensamiento y trayectoria de un monárquico, Cádiz, Servicio de Publicaciones de la Universidad de Cádiz, pp. 129-262. En la interpretación de F. Kermode los libros de Bardiaev fueron también una especie del apocalipsis sofisticado y moderno. En The sense of an Ending, p.16. 
«Así llegó la hora que parecía señalar el fin de los tiempos» (949), sin embargo, de acuerdo con su papel de consolador, el poeta-vate representa la serpiente que se muerde su cola y de esta manera cierra un círculo, lo cual quiere decir que su tiempo es limitado y las calamidades pronto pasarán. Alude también al Apocalipsis en que el mal se destruye a sí mismo (cf. Ap 17, 16-17).

La división mayor da cabida a una división menor, así que en el «centro» de los tiempos se suceden episodios de enfrentamientos y aclaraciones del sentido. Las historias subsiguientes aparentemente inconexas cobran importancia dentro de un cuadro más amplio. La transición a otro tiempo se realiza también en un momento determinado: «la hora nueva ha llegado; la cosecha está en flor» (1068). Los puntos de viraje en la acción se reflejan por un repentino contraste de imágenes de devastación y felicidad (1007). El desastre se entiende como un intervalo imprescindible para pasar a una época de bienestar, la transición entre las cosas primeras y las nuevas, como lo vemos en las palabras de la Nube:

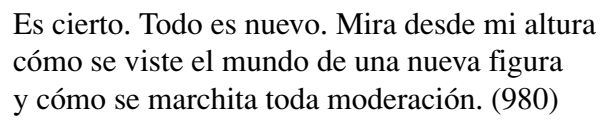

Es una tendencia común de los poetas apocalípticos ver la guerra y la destrucción como una transición necesaria hacia la renovación ${ }^{50}$. La guerra se vuelve santa cuando se espera que restablezca la justicia en el mundo histórico. Su decadencia paradójicamente erradica el caos y trae la esperanza del feliz desenlace. Se desencadena entre las categorías últimas de la realidad, el bien y el mal ${ }^{51}$. En este sentido el Poema es apocalíptico pero no escatológico, porque se dirige «hacia» una etapa nueva y no predica lo que va a llegar después de la muerte. No anuncia el fin del mundo, sino la transición a la renovación. Tradicionalmente la muerte precede el juicio que divide a los muertos. El Poema no aventura las imágenes del juicio final sino que lo aplaza y cede ante la incógnita de los designios divinos en los que no quiere intervenir. No se pronuncia sobre el destino de los muertos.

Las formas de aparición del poeta en las visiones tienen su ritmo. Entra en escena desde las alturas celestiales. El canto central vuelve a la realidad terrestre y baja el tono, pero en medio de lo real inserta de nuevo la batalla sobrenatural entre el Ángel y la Bestia. En el canto tercero de nuevo plantea el trasfondo trascendente. Vemos que dibuja una especie de paraíso terrenal español, sin embargo vuelve a la tierra y anuncia que el verdadero ideal todavía está por venir y sigue en el tiempo de esperanza. Los tiempos después de la batalla siguen fluyendo hacia el punto omega de su historia. La Alegría vaticina:

Y años vendrán, añado yo, en que, como los mares ayer, se abrirá el cielo,

Se forzarán los límites de esa otra

\footnotetext{
${ }^{50}$ Kermode, F.: The sense of an Ending, p. 98.

51 Aho, James A. (1981): Religious mythology and the art of war: Comparative religious symbolism of military violence, London, Aldwych Press, pp. 11, 148-156.
} 


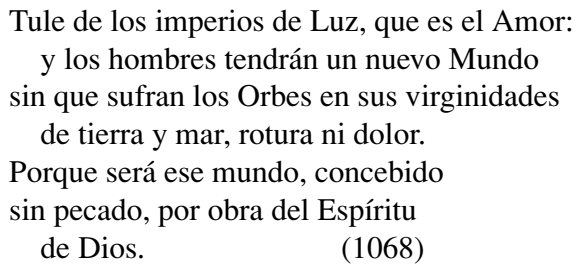

A pesar de esta nota que pretende ser universal y sobrenatural, el Poema insiste en la victoria temporal en esa guerra concreta. Dista por tanto de los apocalipsis que preferían guardar un prudente silencio acerca del resultado visible en la tierra y predicaban la victoria intemporal y por encima de los resultados momentáneos. Aquí vemos una especie de localismo apocalíptico.

En los apocalipsis y en el Poema el conflicto entre el bien y el mal es más real en el cielo que en la tierra, de modo que prevalecen las descripciones del mundo invisible y se presta más importancia a su desenlace final que repercute en el mundo de abajo. La guerra en la tierra refleja algo del conflicto universal y las peripecias de los individuos manifiestan el conflicto de los poderes cósmicos ${ }^{52}$. También al revés: los apocalipsis no olvidan que lo particular y lo universal se entrecruzan, así que los acontecimientos menores provocan consecuencias a gran escala en el cielo. En este sentido Pemán, al lado de cuadros llenos de hipérboles sobre el trasfondo trascendente, menciona otros países europeos cuyo destino universal está pendiente del destino particular español. Además, alterna la trama con el localismo de los niños sevillanos bailando, de una niña bajo los disparos de los aviones o de unas madres que lloran. En fin, la batalla final no se lleva a cabo en el cielo ni en el aire, ni en ningún lugar impreciso sino en el suelo ibérico, con referencias geográficas concretas, la Bestia se muere en las breñas de Asturias.

La oscilación entre lo grandioso y lo pequeño se ilustra especialmente en el fragmento «Los dones de las tres hadas». Coincide con los típicos cuadros bíblicos, donde la historia se decide en detalles y en un lugar aparentemente insignificante. A semejanza del pequeño Belén, aparece un pueblo perdido en Galicia donde encontramos a un niño recién nacido (Franco en este papel). Como agente sobrenatural aquí intervienen tres hadas que muestran un parecido con los reyes magos y traen regalos: la espada con puño de oro, una pesa de plata y una sonrisa (973). Este cuadro cumple con el tópico de las circunstancias sobrenaturales del nacimiento de un héroe y de un arma milagrosa que va a llevar y que en este caso anuncia la guerra.

El Poema adapta motivos de uso corriente en la apocalíptica. Representa la Iglesia como una entidad mística, la unidad de los santos en la tierra y en el cielo (935), repetidos sonidos de trompetas y campanas, se oye la música celeste, Dios tiene vestidos blancos como la nieve, aparece el «valle de los huesos» (974), los fieles están dispersos, así que invoca a las tierras africanas a que se unan a España (975), la representación alegórica de la lujuria recuerda la prostituta del Apocalipsis (974), las sucesivas lamentaciones apocalípticas destacan en el fragmento «Romance de los muertos en el campo», la ciudad de Santiago de Compostela se convierte en Jerusalén a nivel español, el baluarte

${ }^{52}$ Emmerson, R. K. y Herzmann, R. B.: op. cit., p. 126. 
espiritual donde converge todo (938). El tiempo de prueba sirve para cambiar a la gente: «Yo haré puros, metiendo despojos de martirio./ (...) Haré los hombres sabios» (984); «La purificación y el mejoramiento que la Guerra trae a las almas» (1041). Encontramos la soledad del testimonio frente al resto del mundo (969), la persecución de los fieles, por parte de los judíos en este caso, la presencia de dos caminos entre los que hay que elegir. El Poema evoca el martirio de los primeros cristianos reproducido en la actualidad. Al mismo tiempo, como los apocalipsis buscaban figuras de testigos que representaran al pueblo y el de Juan habla en concreto de dos testigos, aquí aparecen dos tipos destacados: José Calvo Sotelo y Franco. El primero se presenta como un ardiente profeta: «Sus pupilas sin fondo llameaban/ de ira santa y de vergüenza» (968) y sufre su «vía crucis». Su muerte iniciará la gran batalla. Completa la idea con la descripción de la resistencia de los personajes sencillos (cf. 955-956).

El Poema sobrepone las situaciones universales de la Biblia en las particulares de la historia o de la guerra en concreto. La enemistad entre la serpiente y la mujer se traslada a la de los judíos y la reina Isabel (965), África es presentada como la amada del Cantar de los cantares (975), Lutero participa en la historia de la tentación del árbol de la ciencia (1004), el coronel Moscardó y su hijo traen recuerdo de la cruz y de la corona de espinas, aparece el motivo del sufrimiento que borra las culpas $(999,1007)$, España lleva los atributos de Cristo crucificado (las espinas, las manos clavadas, etc.) (988), alude al sacrificio de Isaac (1032). Dentro del texto el poeta introduce varios fragmentos sueltos del Apocalipsis de Juan: los coros celestiales alzan sus aleluyas y el ángel tira al mar la piedra-Babilonia (1041-1042), suenan las trompetas que anuncian la consumación de lo viejo, etc. Aludiendo a la presencia de la figura de la Virgen en el Apocalipsis, aquí también el poeta busca apoyo en su figura, aunque al margen de los acontecimientos (953, 963, 993, 1036).

La venida del ángel custodio de España es una réplica de la aparición del hijo del hombre en el libro de Daniel $(7,13)$ y en el Apocalipsis $(14,14)$ :

Pero mirad, hermanos: ¿quién es aquel que viene
sobre una nube, y tiene
los pies rojos y azules como llamas del fuego,
y el casco de arco iris, y la cara de sol?

O son los elementos naturales que aluden a las palabras bíblicas: «ßBendito aquél que llega con la boca encendida/ de verdades, por campos de turquesa y zafir!» (986).

El cuadro interno se extiende mediante el paralelismo en la construcción, y entre lo particular y lo universal. Es visible en la presencia de dos batallas. La sobrenatural entre la Bestia y el Ángel aragonés acarrea una victoria en el plano natural y a la inversa, la batalla real y particular, el sito del Alcázar de Toledo, entra en la batalla universal y repercute en «los Mundos» (1011). Toledo se convierte en un símbolo profanado y corresponde al motivo apocalíptico de la destrucción física de un templo. Es un acontecimiento anunciado por la trompeta, y también tiene sus mártires (el coronel Moscardó y su hijo), según los moldes apocalípticos.

El fragmento «Pelea de la Bestia y el Ángel» se convierte en el núcleo del tiempo y desemboca en una época de bienestar. El poeta asegura que todos los episodios aislados 
de la guerra manifiestan su verdadero trasfondo en la batalla, el conflicto entre la materia y el espíritu (1032). Vemos que el poeta dota de cualidades espaciales lo que transcurrió en las categorías temporales ${ }^{53}$. Colindan los poderes invisibles con los reales de la infantería, aviación, los barcos, etc. en una imagen de gran envergadura de los sucesos. Frente al despliegue del espanto y poder de la Bestia, rodeada de efectos sonoros y visuales espectaculares, se sitúa un infante aragonés, que en algunos momentos es el Ángel y en otros algún poeta, representado en términos de inocencia y alegría. El poeta no admite otro resultado que la victoria y alude que la batalla es repetición del arquetipo del enfrentamiento entre San Jorge y el dragón, San Miguel y Satanás, las Gracias y las Furias. Varias imágenes paralelas crean la idea de la desproporcionalidad de las fuerzas. Se repite el esquema: «El carro es todo poder/ él todo fragilidad» (1035), «flor que vence al huracán» (1037), etc. La procedencia elevada del Ángel y las anteriores alturas contrastan con los rasgos de la Bestia que se arrastra por el suelo y le acompaña el «soplo bajo de la tarde». Para que la batalla sea más universal el poeta explica que no sólo se enfrentan la verdad y la mentira (1036) sino también la poesía de la belleza y la prosa proletaria (1033). El carro representa el capitalismo y el comunismo en uno. Se repite el concepto del mal que se destruye a sí mismo: «Las bocas que tenía para matar, sirvieron/ al Ángel para herirle en el costado» (1039).

Otro rasgo determinante de los apocalipsis es la reinterpretación del pasado desde la óptica del final. Se trata de acontecimientos inevitables, ya previstos en la economía divina, y por tanto lo ven todo a la luz del final cercano e inminente. Así, el autor transmite un mensaje optimista en que todo se encamina hacia una buena solución y anima a que el tiempo de la tribulación se explique sólo por el final feliz. El mundo nuevo está a la vuelta de la esquina. Desde el principio da el consuelo de que las calamidades serán vanas y la Iglesia española saldrá airosa pero gracias al apoyo divino.

Señala J. A. Díaz que estos autores son «totalmente deterministas», y la única solución admitida es la victoria. Por eso, aparentemente, se complacen en la destrucción porque ven en ella el presagio del porvenir idílico. Además, según el planteamiento apocalíptico la sangre es derramada universalmente como precio de la transición, pues se promete la llegada de un tiempo que solucionará todos los enigmas del sufrimiento, incomprensibles ahora. El final victorioso es la única justificación de la esperanza que desde el futuro ilumina a los que sufren ${ }^{54}$. Pemán tiene prevista la feliz conclusión y en el prólogo escribe: «He creído antes de ver» (927). En «Paz en los pueblos» la monarquía es lo que sueña, pero asegura que ya la ve. Sistemáticamente manifiesta su certeza de la victoria y fortalece el ánimo de los oyentes (953). Da consuelos anticipativos: «Detrás de las tinieblas viene siempre la Luz» (983). Fomenta las «ansias de nueva edad clara y florida» (994). En «Himno de la abundancia» dice que la prosperidad se vislumbraba desde los principios de la guerra. Las imágenes históricas se presentan como encaminadas al final feliz, contemplado ya por el vate (975).

El mundo de los apocalipsis incluye con frecuencia la idea de la aniquilación total que da principio a la renovación. La redención se realiza a costa del dolor (988), y el po-

${ }^{53}$ Cf. Kermode, F.: «The New Apocalyptists», p. 361.

${ }^{54}$ Aho, James A.: op. cit., p. 11. Díaz, J. A.: op. cit., pp. 101-102, 110, 216. Kermode, F.: The sense of an Ending, p. 107. 
eta exclama: «La muerte que engendra la vida-la niebla que esconde luces» (1018). En ocasiones este vaticinio colinda con imágenes morbosas:

¡Paradoja de la muerte-que tanta vida produce!

Movimiento de gusanos-sobre las frías quietudes.

Espumas de margaritas-abierta una boca escupe.

Macetas de jaramago-son unos ojos sin luces. (1018)

Justifica la guerra y la muerte como la transición a la paz y renovación (998, 1044, 1052), hacia el «Capítulo Nuevo» de la historia (1024). Se repite al motivo apocalíptico de la vuelta de la luz de otro origen (993). En medio, el poeta se acuerda de su homenaje a la épica antigua e inserta la invocación a la diosa de la abundancia y presenta el país como la homérica tierra de idilio. La Alegría profetiza el glorioso futuro del imperio. Se instaura el orden idílico, la paz celestial se refleja en la tierra, se elevan cantos para la eternidad (1061-1062), los humanos se vuelven más etéreos y traspasados por la luz (1063). Se profesa también una nueva época para la poesía que ha vencido el mal (1040). El canto de «El sereno Aleluya» se alza en el paraíso español.

Los autores del género apocalíptico creían descubrir al Anticristo en Nerón o cualquier otro personaje que amenazaba al cristianismo. La bestia se identificaba con un conjunto de falsos profetas o los imperios enteros ${ }^{55}$. En el Poema, la Bestia elige a su representante-anticristo en la figura del cordero, como más abajo veremos. Los intereses de los apocalípticos tradicionalmente no coinciden con los de los reyes o políticos. Así, para Pemán las bestias representan a instituciones, grupos o ideologías (la masonería, los judíos, el comunismo, el capitalismo). Reviste a los judíos de los rasgos de la Bestia, con referencias a su posición en el capitalismo y la supuesta conjura con la masonería. En esta ocasión el antisemitismo se inserta dentro de la corriente tanto apocalíptica como política. El papel de los judíos en la apocalíptica no es nada despreciable porque su conversión aparece como uno de los anuncios del fin del mundo. Cada movimiento interno o externo a gran escala de esa raza fomentaba las profecías escatológicas, como por ejemplo sucedió tras su expulsión de España. El antisemitismo era común a los apocalipsis de la Edad Media, que veían en los judíos la prefiguración del Anticristo ${ }^{56}$. Por otro lado, a principios del siglo XX, renacieron las sospechas hacia ellos. El análisis de ese fenómeno se detalla en varios estudios de Gonzalo Álvarez Chillida. Recuerda que ya antes de la guerra proliferaban los escritos antisemitas. De especial relieve fueron Los protocolos de los Sabios de Sión, reeditados en España en 1927, 1932, 1936. Pemán de hecho hace referencia al «Sabio de Sión» y calca muchos tópicos de este libro (950 y ss.). Por otra parte, las reticencias del poeta no se dirigieron a la raza judía sino a un bloque de preceptos espirituales que veía en ellos. Pasado el tiempo Pemán se distanció de afirmaciones tan tajantes $^{57}$. Fue una trayectoria compartida por otros poetas en los que coincidieron las ten-

55 Díaz, J. A.: op. cit., p. 116. Emmerson, R. K. y Herzmann, R. B.: op. cit., p. 9. Giet, S.: op. cit., p. 187.

${ }^{56}$ Cf. Fatás, G.: op. cit., p. 109. Kermode, F.: The sense of an Ending, p. 109, «The New Apocalyptists», p. 350.

57 Álvarez Chillida, Gonzalo (2002): El Antisemitismo en España. La imagen del judío (1812-2002), Madrid, Marcial Pons, pp. 182-184, 301-377. José María Pemán..., pp. 339-366. Tusell, Javier y Álvarez Chillida, Gonzalo (1998): Pemán. Un trayecto intelectual desde la extrema derecha hasta la democracia, Barcelona, Planeta, p. 58 . 
dencias nacionalistas con los mensajes apocalípticos, y que demonizaron a los judíos como en el caso de T. S. Eliot o Wyndham Lewis ${ }^{58}$. Desde otro lado, J. Caminero interpreta que incluso Lorca no fue ajeno a las ideas antijudías y ve indicios de antisemitismo en su obra ${ }^{59}$.

El Poema explota las características de la Bestia acumuladas en varios apocalipsis. En el Antiguo Testamento las grandes aguas son la sede del mal. De forma parecida el Poema relaciona el mar con las fuerzas malignas $(941,1015)$. Además, la bestia apocalíptica tiene su falso profeta, o es el dragón-Satanás que tiene una especie de doble de la bestia parecida a un cordero (Ap 13,11). En el Poema la Bestia elige al cordero y bajo este disfraz se manifiesta. De esta manera se realiza la típica trasposición de animales parecidos ${ }^{60}$.

En varias etapas del Poema la Bestia falsifica las acciones del bien actuando paralelamente. Su actuación parodia a Cristo y cada acto del bien encuentra su equivalente falso ${ }^{61}$ :

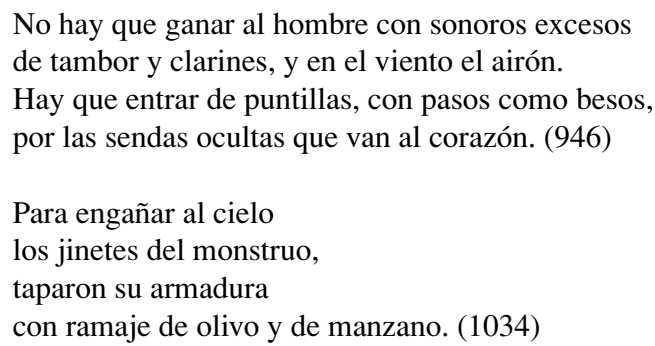

Representa la destrucción y profanación de la belleza (941), el falso cordero copia el bien $(939,941,945)$, lo torcido de la serpiente se opone a la exactitud de la Cruz (943), disfrazada de cordero alterna los valores: «La Nada es libre: pero el Ser, esclavo» (948). El «Diálogo» introduce el motivo del árbol de la vida en el Edén y el motivo de la Bestia que subyuga y tienta con la palabra (943-945). El poeta enumera varias imágenes del cordero que seduce por la belleza, la ciencia, el amor, el placer, la ilusión de la libertad en la vida y en el arte, la belleza de la poesía (45-46). Pero señala que son valores desprendidos de su origen y finalidad (947-948).

Las obras apocalípticas crean su propio bestiario, que en el Poema es bastante abundante en alegorías y metáforas. En general, son bestias las empresas capitalistas, unos seres pegajosos con muchas patas y cabezas de chivo, que pretenden martirizar a España. Son el pulpo americano de mil brazos y el leopardo inglés (970-971). El leopardo enlaza con el Apocalipsis de Juan, donde entre las dos bestias, la que se parece a una pantera emerge del mar (Ap 13,1-2). El repertorio se amplía con un águila de la guerra (977), la pantera de Liberia de la «boca fiera» (990), los ojos a modo de un lobo que sitian Oviedo (995), los «topos oscuros» (1008), un «espíritu de hiena» (1009), el avión como un «pájaro gris de hierro y fuego» (1031), la muerte como un lobo que acecha

\footnotetext{
${ }^{58}$ Kermode, F.: «The New Apocalyptists», pp. 351-352.

${ }^{59}$ Caminero, J.: op. cit., p. 223.

${ }^{60}$ Giet, S.: op. cit., p. 38.

${ }^{61}$ Emmerson, R. K. y Herzmann, R. B.: op. cit., p. 12.
} 